\title{
STREETS BY THE SEA \\ Type-morphology of Portuguese Atlantic waterfront facing sea level rise
}

\author{
Dal Cin, Francesca \\ FormaUrbis LAB, CIAUD, Lisbon School of Architecture, Universidade de Lisboa, \\ Rua Sá Nogueira, 1349-063 Lisboa, Portugal \\ francescadalcin.fdc@gmail.com
}

\section{RESUMEN}

Global warming affects the city and the interaction of anthropogenic systems. Among the effects of climate change, there is an increase in the average sea level, as reported by the IPCC. In an unpredictable future of climate change where cities are vulnerable anthropic systems, it is required to make cities climate-proof. This thesis research focuses on the seashore street, in the Portuguese coastal cities. The relationship between water and the built area defines a territory that has been considered habitable and that over time has developed different forms of use: fishing, port, and today is a recreational place.

The aim is to describe seashore streets' characteristics in the space through a morphological analysis of its spatial dimension evolution in time. Furthermore to understand what happens when the urban and the Atlantic overlap. The identification and classification of this part of the city is the first step for its adaptation.

Palabras clave: Seashore Streets, Urban Morphology, Impact Assessment, Sea Level Rise Bloque temático: Morfologías Urbanas 


\section{Introduction}

Designing in a changing climate plays a decisive role in preparing the city for the impact of global warming through actions and design approaches useful to increasing the adaptive capabilities of cities. The examination of adaptation plans, urban design strategies, climate proof policies in response to climate change, become a fundamental element for city planning; aware that in the near future we will have to live more and more with the unpredictability and increasing intensity of extreme weather phenomena. Contemporary it is urgent to study adaptation and measures of urban fabrics and there is the need to rethink open spaces through the stratification of functions and uses, intertwining the 'extraordinary' events of climate change and the 'ordinary' of living in the city.

The morphological study of this space that lies between the city and the water, seashore streets or "Rua Marginal", can be defined as paradigmatic for its forms in relation to the contemporary city. Therefore, as stated by Paola Viganò, in her text La città elementare, "observing some materials of the contemporary city and describing them, means resuming and deepening the research path." (Viganò, 1999: 29) In this dissertation, we will addresses the morphological cataloguing of Portuguese seashore streets, understanding and explaining the transformations of this part of the coastal cities.

This procedure requires the development of classification systems capable of dividing the study cases of Portuguese seashore streets into groups defined by controllable and reproducible rules. Because that territory has similar characteristics but not exactly identical and homogeneous it therefore requires a cataloguing to be able to demonstrate the importance of obtaining a "previous classification" of study case, where to cross the morphological data.

The aim is to draft a type-morphological framework, which investigates "the critical-relational character between underlying tissue and new morphological-type updating factors and that of the search for a possible language of modernity based on the intersection of historical and new codes. dimensional and technological scenarios." (Riondino, 2012: 196) Thus, through the creation of a morphological type framework, we can identify a space on the border between the city and the sea, which we identify as seashore street. Definition that will be useful as a basis to research and design this third landscape, based on its memory and facing an expected sea level rise.

The PhD thesis started in September 2017. As a university scholarship winner, with a duration of three years starting from June 2018, it is possible that the doctorate will extend for a maximum duration of 4 years.

\section{Problem contextualization}

2016 was the hottest year on Earth since 1880 - the date on which we start to have scientific data on climate, - the global temperature on land and on the ocean surface was 0.94 degrees Celsius above the $20^{\text {th }}$ century media, as certified by NASA and the US Federal Agency for Meteorology (NOAA).

Global warming affects the city and the interaction of anthropogenic systems. Among the effects of climate change such as rising temperatures, there is an increase in the average sea level, as reported by the IPCC. The increasingly alarming consequences of this rise, require the conscious management, the development of models and the drafting of measures suitable for intervention to facilitate the adaptation of the part of the city most vulnerable to flooding.

The uncertainty that characterizes the design of the contemporary city, is also due to scenarios of unpredictability of the climate and it is for this reason that is necessary to investigate new processes of planning and management of the territory by improving the integration between science and urban planning. (Costa, 2013: 125)

In this historical moment, governments' inability to control the evolution of climate change requires adaptive interventions on the urban system. Managing and planning the territory and the city in scenarios of unpredictability, through a possible forecast, in a framework made up of various environmental factors, is the aim of a new urban planning that learns to live with uncertainty. 
The increase of the average sea level poses new problems, where the main one is to understand which spaces of the coastal cities will undergo flooding processes.

In summary, the predictability of recurrently published data regarding Sea Level Rise (SLR), emissions of greenhouse gases and socio-economic tendencies continues to consolidate and aluminated the relevant tools that urbanism has to use in creating adequate adaptation measures. (Costa et al, 2014)

\section{Object of study}

The Portuguese coastal territory extends for $943 \mathrm{~km}$ and about $80 \%$ of the population live there, due to the consequences of climate change, this territory is particularly vulnerable. In this context, it is essential to study and understand the vulnerable parts of the city to try to prevent problems due to the increase in the average sea level, such as floods in the city.

Through an almost geometric approach we want to investigate the physical components of the city and the sea, the "in-between" space. A space of difficult description to which the term "Seashore Street", or in Portuguese "Rua Marginal" is not sufficient for a through characterization having in mind an intervention (Fig. 01). Because this space is not a line but has a thickness, it is not only a street, it is rather a space to which it has not yet been possible to attribute its borders and margins. In fact it can be described as a strip or a belt, an area where the urban and the Atlantic overlap, which is not fixed but mobile: we think above all in relation to the rise of the average sea level and the affected urban fabrics of coastal settlements.

The purpose of the thesis is to define the urban object in its characteristics to be able to operate thereafter, because until now it is treated as a "grey spot." Grey spot in which, at the moment, it is not possible to understand the relationship between urban morphology and the phenomenon of flooding, due to climate changes.
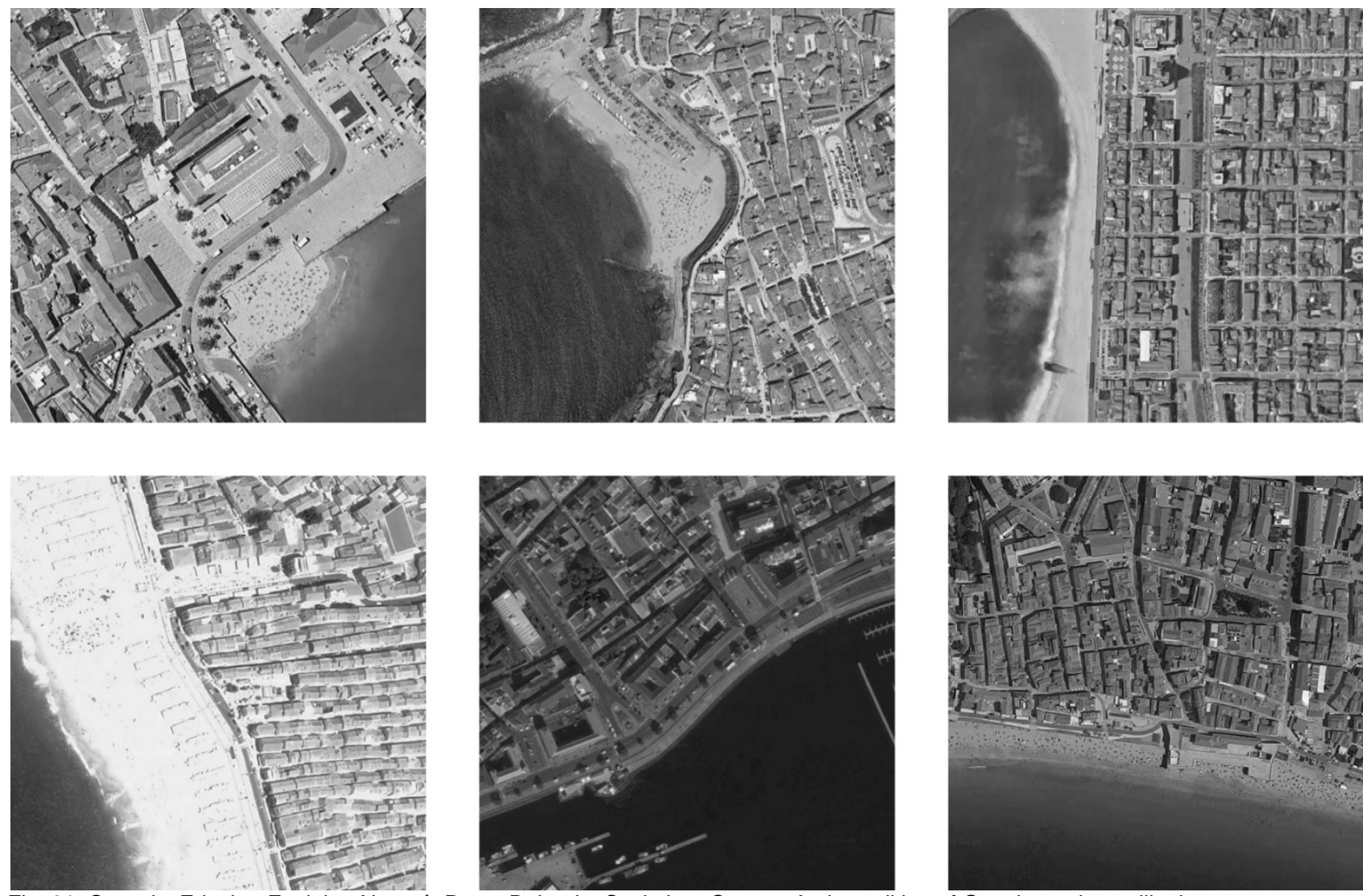

Fig. 01: Cascais, Ericeira, Espinho, Nazaré, Ponta Delgada, Sesimbra. Source: Author edition of Google earth satellite images. 


\section{Research question}

It is necessary to highlight the starting point or that the present context of climate change effects on Portuguese coastal settlements is an opportunity to rethink and plan the transformation and adaptation of the seashore street.

The main question we will try to answer through this research is:

- How are Portuguese seashore streets formed?

Based on a type-morphological approach we expect that the explanation of the types of seashore and their formation process will be useful for the design of future waterfront spaces based on their memory. Because the relationship between water and the built area defines a territory that from $19^{\text {th }}$ century was considered habitable and developed different forms of use. It was originated form the needs arising from the port and the fishing activity; today it is a leisure space used primarily as a touristic place (Fig. 02).

Other questions related to the first, are:

- Is the type of the seashore street a landscape that belongs to the past or will it undergo an evolution? Which parts of seashore streets are more vulnerable to SLR?

- How to integrate their heritage value (in case they have it) in the adaptation measures and transformations?

- What role does a type-morphological framework play in studying that fragile territory in relation to climate change?

- What is the importance of urban form and morphology in the delineation of resilient urban planning?
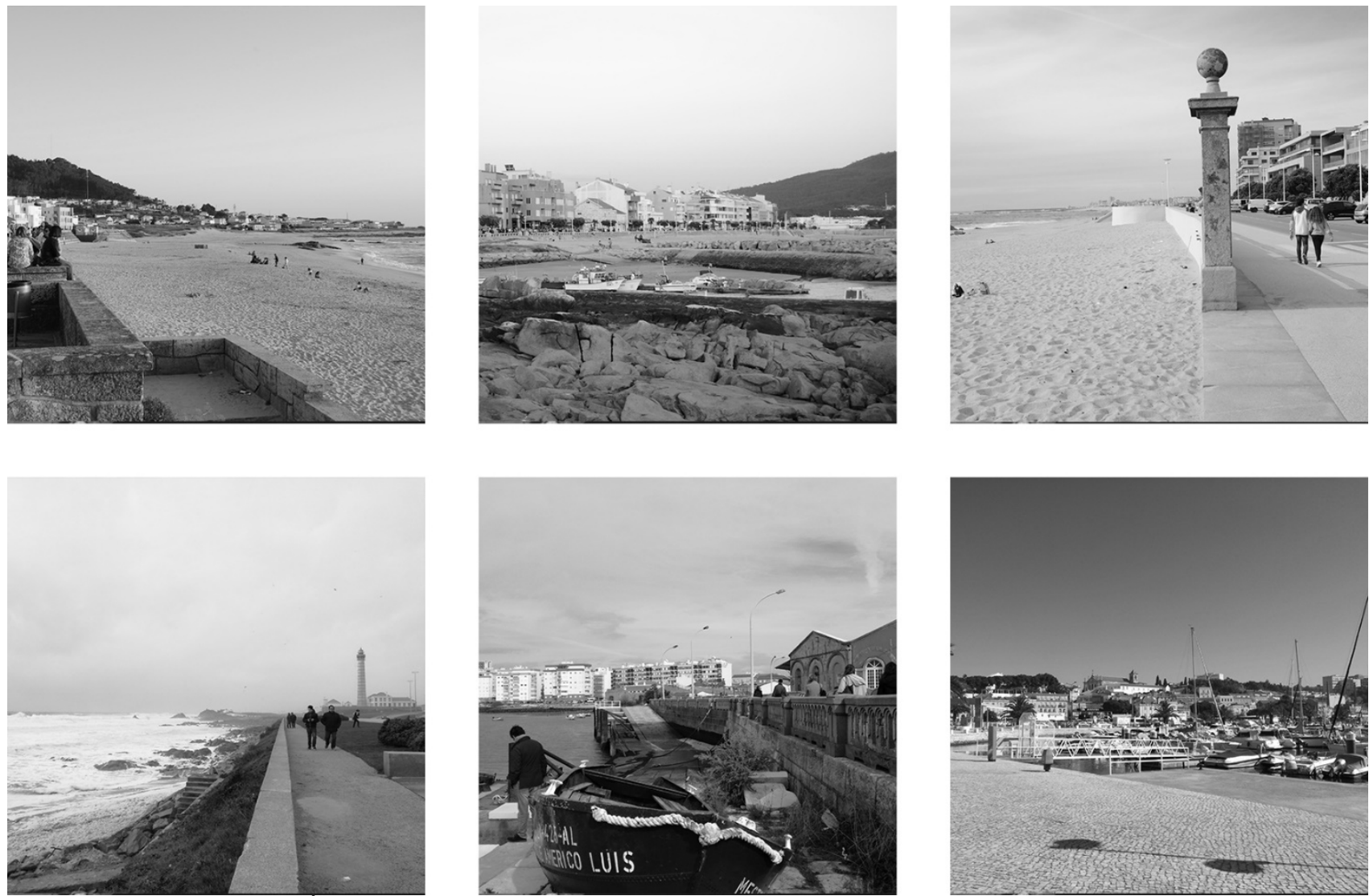

Fig. 02: Moledo, Vila Praia de Âncora, Vila do Conde, Matosinhos, Barreiro, Setúbal. Source: Author edition. 


\section{Objectives}

The main objective, is to create a type-morphological framework that identifies, defines and organizes different morphological types of Portuguese seashore streets. We aim also to identify, name and describe, this vulnerable and important space where the city and the sea overlap.

The aim of the type-morphological framework is:

- To study the Portuguese coasts in their relationship between the morphology of the territory and the built, in relation with the rise of the average sea level.

- To define a classification of the Portuguese seashore street that allows the elaboration of a reference typological framework.

- To decipher the formation and transformation processes, through the analysis of case studies present in the national territory.

As Paola Viganò wrote in 1999, the importance of creating a typological framework is to "observe the changing of the elements that make up the city and the territory" to obtain "a window from which to read the transformations." (Viganò, 1999: 85)

As will be better described in the chapter Benefits, writing the type-morphological framework of the seashore street has the benefit and future contribution of being a valid basis:

- To study a solution for the seashore streets, affected by the rise of the average sea level, through the adaptative project of public space.

\section{State of the art}

The state of the art of this research is based on two main topics: urban morphology and climate change. The interaction between the two terms makes it possible to construct the project proposal. For the study of the urban morphology of the seashore street, we will compose a state of the art starting from the different school of thought.

It is necessary to underline that the element of the boundary street, of the margin between the coast and the water, has not yet been studied and described except in relation to a larger space that is the urban waterfront.

For this reason, therefore, the theoretical critical concern of the physical form of the seashore street can be defined by analysing the concept of street. Through the theoretical contextualization we tried to critically expose the importance of the knowledge of the street in the modern city, of its description and representation to rethink the morphological forms of the city.

The thought of Saverio Muratori and of the Italian School is of great importance for drawing up a typemorphological framework, a classification of the Portuguese seashore streets. The typological analysis taught between 1950 and 1960 by Saverio Muratori and Carlo Aymonino, was centred on the survey that relates the relationship between urban morphology and the built typology to understand the typological process, the evolutionary process of the evolution of the fabric of the city, to generate new types.

In the same years, Aldo Rossi introduces the rigour of the layout and of the forms into the design of the city, describing the dependence of the urban form with the typology of the city, contrasting the morphology of the traditional city with the modern one. Rossi, describing the urban form according to the elements that structure the city, anticipates the idea of an abacus categorization.

The use of a categorization abacus, a type-morphological framework, is useful because "the types function as a proposition for reproduction." (Panerai, Depaule, Demorgon, 1999: 106)

Aldo Rossi, also, in 1966 considers the street as the fundamental fixed point for the configuration of the city in today's urban dynamics. Almost in the same year Jane Jacobs states that the street, above all pedestrian is the 
seat of social activities and in 1975 Krier states that the elementary units of the city are the street and the square which dictate the rules of urban composition.

Franco Purini declared that understanding the structure of the plot in its inertial components and its dynamic values does not seem possible without the "reconstruction" of its origin. (Purini, 2000: 274) Bernardo Secchi in 1989 wrote in the article "Lo spessore della strada" that what is needed to give back to the road its functional and semantic depth, is making it become a constituent element of the urban and territorial project.

Jacobs in his book, titled Great Streets (1993), studied many types of street in the world, from Pittsburgh to Beijing and he produced more than 200 illustrations. He drew different streets and this book is interesting for the quality of the information about the space that Jacobs analysed. The reference to this book is important for the value that the author gives to the drawing, such as a tool to describe and investigate the city.

In 1999 Panerai, Demorgon and Depaule stated that the analysis of public space can be made from different points of view: as a global system that constitutes the structure of the urban form.

"The public space includes all the streets: streets and alleys, avenues and avenues, squares and squares, walks, docks and bridges but also rivers and canals, banks and beaches. This set is organized in a network to allow distribution and circulation. "(Panerai, Demorgon, Depaule, 1999: 78)

Finally, quoting the text "La città elementare" by Paola Viganò, "the architecture of the city changes its role in relation to the ambiguity of the concept of urban form" (1999: 113)

\section{Hypothesis}

It is necessary to underline the importance of the assumptions to this investigation, as follows: the increase in the average sea level, as reported by the IPCC, is directly connected to the morphology of the territory and of the built of those parts of the city that are the most vulnerable to flooding.

Where the effects of climate change can be seen as an opportunity to re-think and re-design the contemporary city starting from the marginal areas between the built up and the water. The study of marginal public space can be interpreted as an opportunity to investigate the debate on the contemporary city and above all achieves the recovery of values and identifiable quality in the concept of city.

It is considered that:

- It is not possible to understand and anticipate the effects of climate change on the seashore street without knowing the relationship between the morphology of the urban element and the raising of the average sea level.

For this reason, the hypotheses are:

- It is not possible to decode the seashore street without observing the consolidated urban space, its morphology, morphogenesis and transformation.

- It is not possible to adapt the seashore street to climate change without carrying out a morphological study.

In this thesis it is placed the hypotheses that the knowledge on the formation process of seashore streets is essential to tackle the challenge of the effects of SLR on coastal urban fabrics. This knowledge may be achieved with a type-morphological analysis of seashore streets and the composition of a type morphological framework of these spaces coupled with local SLR scenarios, leading to the definition of a third landscape, essential for the design of a adaptation measures (Fig. 03). 

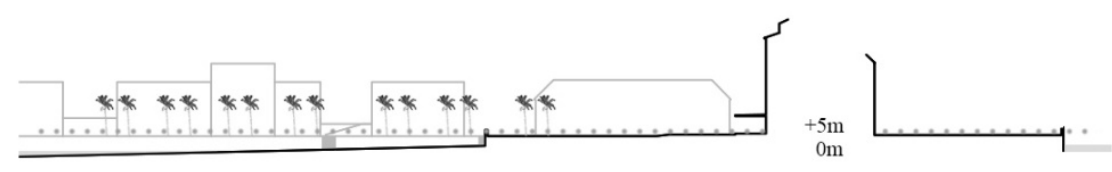

$A-A^{\prime}$

CASCAIS

B - B'

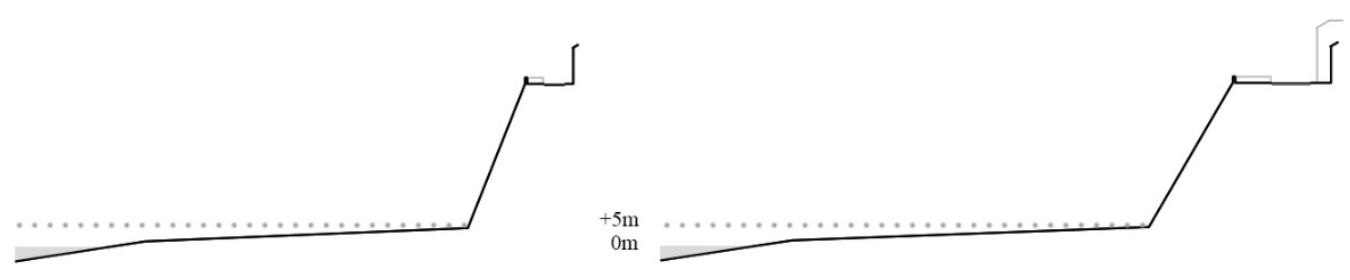

$A-A^{\prime}$

ERICEIRA

B - B'

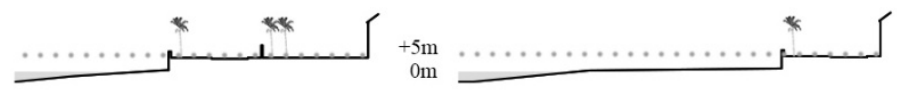

$\begin{array}{lll}\text { A - A } & \text { ESPINHO }\end{array}$

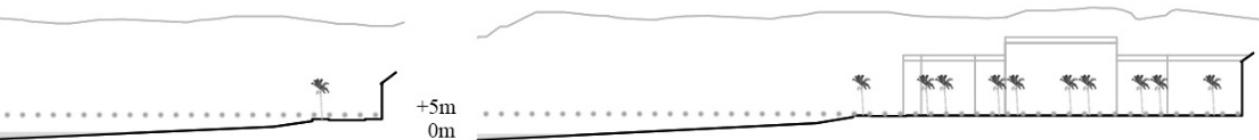

$\begin{array}{lll}\text { A - A' NAZARÉ } & \text { B - B' }\end{array}$

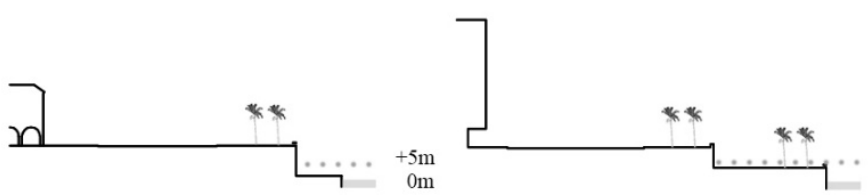

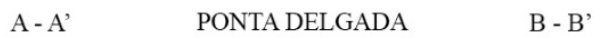

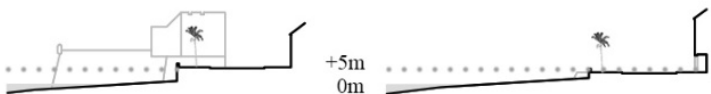

$\begin{array}{lll}\text { A - } A^{\prime} & \text { SESIMBRA }\end{array}$

Fig. 03: Cross sections of seashore street of Cascais, Ericeira, Espinho, Nazaré, Ponta Delgada, Sesimbra, considering a $+5 \mathrm{~m}$ sea level rise. Source: Author edition.

\section{Research Design}

To achieve the results of the investigation and therefore to analyse and better evolve the study theme, reference was made to a combination of methods and techniques, through the collection of data. The empirical data will derive from the analysis of the selected case studies with the intention of analysing the most relevant cases throughout the Portuguese territory.

The methodology, for this research project, will be the reading and interpretation of the case studies to arrive at the understanding of the formation and transformation process of the contemporary seashore street in relation to climate change but above all to the average rise in sea level. 
"In the current context in which climate change promotes a gradual but inevitable sea-level rise, it is essential to know the diversity of seashore street's type as well as to define measures and design their adaptation to climate change, coordinated with the cultural heritage of the urban spaces and the need and aspirations of the populations, who understand them as irreplaceable references both in their daily lives and as representation stages of the exceptional events of society." (Proença, 2018: n.p.)

It is necessary to underline that the intention is to map the main Portuguese coastal cities, to study their morphological evolution, which is why the research will be based on a qualitative and not quantitative analysis. The methodology is ascribable to the non-interventionist paradigm as the empirical data resulting from the morphological analysis of the cities, case studies that will compose the type-morphological framework, will not be modified. We think that drawing up a catalogue through the mapping of the relations between the full and empty spaces of this part of the city, is the first step to promote the adaptation of the city to climate change and to rethink new urban forms. Conscious that through the graphic representation of the case studies there is a better and more rapid perception of the urban space, of the morphological characteristics of the terrain and above all of effects of the raising of the mean sea level. In the meantime is important to underline the importance of the drawing in the scientific research, because it is an important method of investigation proper to urbanarchitectural discipline in the role of a methodological process has.

Research Design is divided into four phases (Fig. 04): Literature Review, Elaboration of database, Local SLR Scenario's Impact, Elaboration of a type-morphological framework, Definition of third landscape.

\section{Literature review}

The research methodology for the thesis project consists of several phases, the first is the study of the different authors who investigate the theme of urban morphology - through the collection, selection, analysis and critical synthesis - and the theme of climate change, specifically the sea level rise, that supports the development of the State of the Art. Through the revision of the literature a detailed State of the Art is established, reviewing and analysing the literature related to the study of the city starting from it's urban form. The stabilization of concepts by elaborating the State of the Art is necessary in order to trace the research guidelines and the hypothesis that will follow.

\section{Elaboration of a database}

For the development of the thesis project, the classification of the elements to be studied, the Portuguese seashore streets, will be fundamental.

The phase of construction of the database will comprise three phases: the Selection, the Collection and the Graphic Restitution of the seashore streets.

The drawing of the morphological elements will be necessary to arrive, through interpretation, to the synthesis of the classification of the studied cases. It is important to underline the importance of the drawing, in this scientific research, for its role in the categorization as a methodological process has. Quoting Panerai, it is through "a first phase of observation that it is possible to identify the differences: plots that add up, overlap, interrupt and re-emerge, affirming the importance of drawing as a means of understanding and making sense." The graphic rendition of the seashore street will take place through the detailed plan drawing, the cross-section and the photography of the element to which add up the drafting of characteristics texts for each individually case study.

Jacobs states that: "Streets are defined in two ways: vertically, which has to do with height of buildings or walls or trees along a street: and horizontally, which has most to do with the length of the spacing between whatever is doing the defining." (pp 277) Jacobs in his book, titled Great Streets (1993), studied many types of street in the world, from Pittsburgh to Beijing and he produced more than 200 illustrations. He drew different streets and this book is interesting for the quality of the information about the space that Jacobs analysed. The reference to this book is important for the value that the author gives to the drawing, such as a tool to describe and investigate the city. Through the graphic and photographic representation of the seashore street, in different periods, it will be possible to investigate the process of formation and transformation over the years. It is essential to perceive the transformation of the seashore street over time because the morphological richness of its urban fabric and space is the result of a process of sedimentation over time, which defines the urban 
layout of the seashore streets and make it recognizable.

The graphic element of the section is an instrument that allows a more evident and immediate perception of the urban space. The cross section, in fact, allows to report the relationship between the width and height of the street and its own characteristics that the two-dimensional representation of the plant does not fully explore. In this case, the characteristics of the seashore street, that through the cross section you can understand, are the buildings, the walls, the arborization, the slope of the coast and the natural element of water. That is, the crosssection allows us to investigate the relationships between the elements that make up the seashore street. It is thus possible to justify the choice of using mainly the cross-section to draw up the initial previous classification of the seashore street under study. The use of the coastline cross section to describe the seashore has been chosen as a graphical approach because it facilitated the study of the topography of the landscape combined with the study of the built city. The plan representation of the seashore street will allow to investigate the relationship of the ground of the buildings with the raising of the average sea level. Furthermore, by drawing up the ground floor plan, it will be possible to investigate the intended use of each space (residential, commercial, services) that will undergo flooding effects.

\section{Local SLR Scenario's Impact for selected Case Studies}

Simultaneously with the preparation of the database, the Local Sea Level Rise scenarios will be drawn up for the selected case studies. To compile the scenarios for raising the average sea level, the data provided by the IDL (Institute Dom Luis) will be used. Through the scientific data on the SLR provided by the institute it will be possible to obtain more accurate scenarios of the local impacts due to climate change.

\section{Elaboration of a Type-Morphological Framework}

The construction of a type-morphology framework is an efficient means to investigate the morphological diversity of the seashore streets of the Portuguese coasts.

For the construction of the type-morphology, - as already discussed in the 2014 "A diversidade da rua na cidade de Lisboa" thesis of Sergio Proença, - we will use the typo-logical analysis method described by Panerai, Depaule, Demorgon which includes four phases: the Identification of the Corpus, the Previous Classification, the Elaboration of the Type-morphology and finally the Typology.

Following the investigation of the seashore street through its identification for case studies is the typo-logical classification the method chosen to code the territory and the elements that compose it.

We used the "previous classification" or rather: "the drawing up of an inventory of the elements elected as representative and their description, highlighting the properties that distinguish them; and the establishment of criteria allowing an initial classification by categories." (Proença, 2014: 81)

The idea of studying the city through the reading of its individual parts was theorized by Aldo Rossi, who said that "the object of urban morphology is not the study of the city understood as a whole" and then by Michele Caja: "in the study of the city we can group the issues into problems organized with an internal aspect and logic." (Caja et al, 2010: pp. 59) Because, quoting Argan in 1965, "when faced with a vast set of phenomena, there is a need to group them and order them by categories and by classes". (Caja et al, 2010: 21)

The "previous classification" requires the drafting of an inventory of elements elected as representative and the description of the properties that distinguish them, thus defining the criteria that allow an initial classification by categories.

Furthermore, the construction of the types takes place through the classification by families of the common properties of the elements, thus emphasizing the collective characteristics. This process of rational abstraction follows to define the type. Also the phase of the construction of a classification will be flanked by the Literature Review as the theoretical part and the practical part of the study will progress simultaneously until reaching the preliminary results.

As stated, the purpose is to demonstrate the role of the type-morphological study of the Portuguese seashore street which is necessary to understand the evolution of that urban element. The need is to rethink the marginal 
space between the cities and the water, - which, due to the rise of the average sea level, could be subject to more or less intense flooding - using a graphical approach.

The morphological description of the seashore street is fundamental to understand the dimensions of the public space and to have a detailed analysis useful to the planning and management of the space in relation to the increase in the average sea level. After the preliminary results are processed, the type-morphological framework is drawn up, the drafting of a methodological reference, for the interpretation of the present and future form of seashore streets.

The results are obtained from the interweaving of the two areas of knowledge, the morphology of the coastal territories of the Portuguese cities, especially in conformity with the "Rua Marginal", in relation to the climatology and future scenarios of rising sea level. Through the crossing of these two areas of knowledge we can reach the conformation of a complete type-morphological framework of possibility flooding and its impression the coastal urban fabrics. Subsequently, the case studies will be collected to compose the type-morphological framework and within this subdivision the ordering elements will be defined. These data will allow to open a debate on the seashore streets regarding the morphological transformation, having certain data to make future project, planning and planning decisions.

\section{Definition of Third Landscape}

In conclusion the definition of the third landscape, or third space, is the last point in the development of the doctoral thesis, coinciding with one of the prefixed objectives. Definition that occurs through the overlap of two areas of knowledge, the study of urban morphology and climate change, with regard to the object of study that for the moment we define seashore street. By defining this space we want to lay the groundwork to discuss what are the best methods to intervene to adapt them to the SLR due to climate change. 
Object of study

THIRD LANDSCAPE

URBAN MORPHOLOGY + SEA LEVEL RISE

Title

\section{STREETS BY THE SEA}

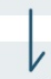

Problem

What is the future of the Third Landscape? Will it be an abandoned place or will it have a new form and function in the city of modernity?

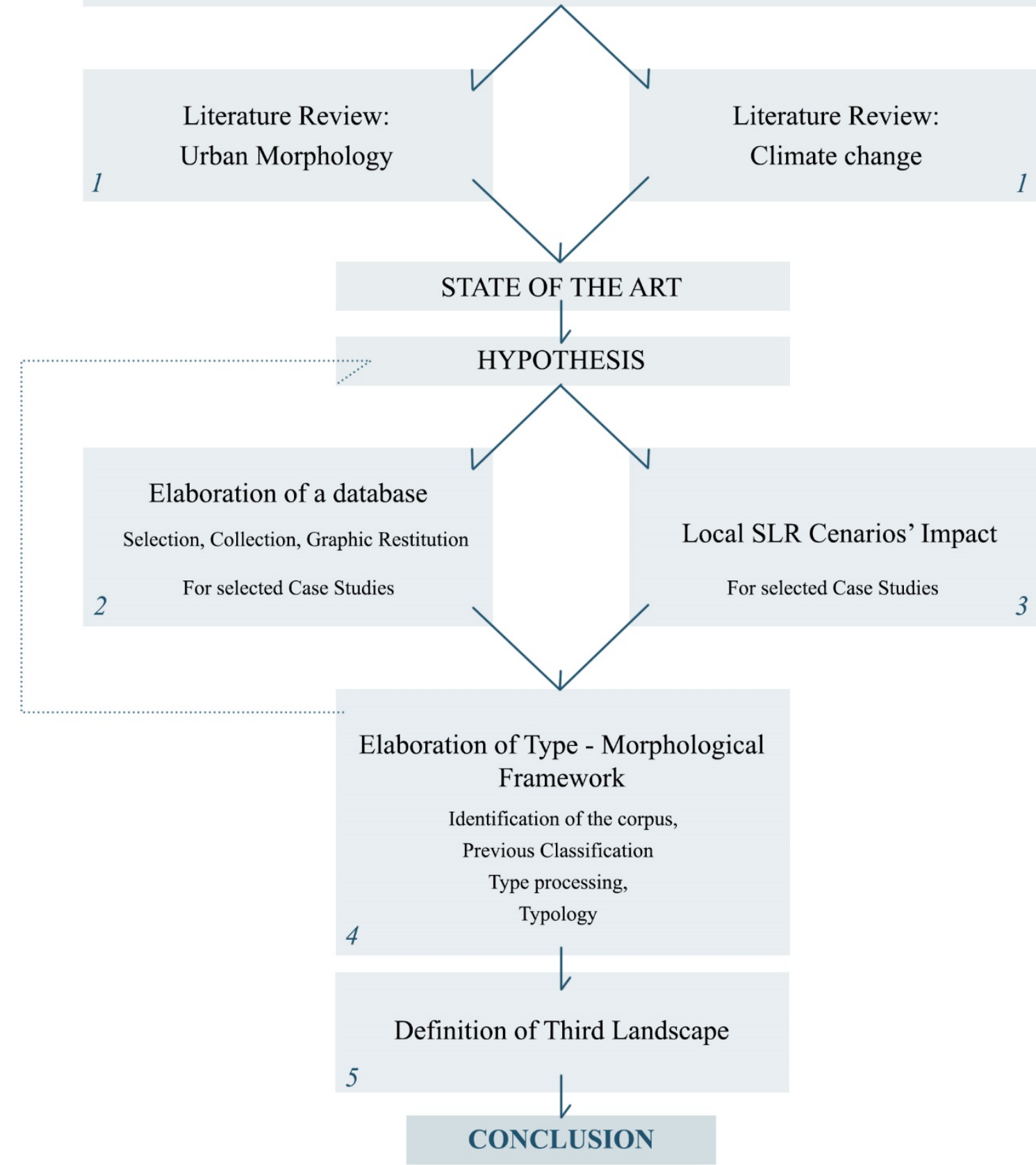




\section{BIBLIOGRAPHY}

APA (2018), Avaliação preliminar dos risco de inundações em Portugal continental. Diretiva N. 2007/60/CE de 23de Outobro. Decreto Lei n. 115/2010, De 22 de Outubro.

ANTUNES, C. y TABORDA, R. (2009). Sea level at Cascais Tide Gauge: Data, Analysis and Results, in Journal of Coastal Research, Portugal, SI 56 (Proceedings of the 10th International Coastal Symposium), 218-222, Lisbon, Potugal.

BOHIGAS, O. (1998). The Street, La strada. En Domus n. 800-810, Uno spazio comune / A common space (47). Milano: Mondadori.

BUSQUETS, J. (1989) Barcellona: una riflessione complessiva. En Casabella 553-554 Sulla strada / About Roads, $(70-77)$. Milano: Mondadori.

CAJA, M. et al. (2010). Tipologia architettonica e morfologia urbana. Il dibattito italiano - antologia 1960-1980, Libraccio, Milano.

CARLOW, V.M. (2016). Limits: Space as Resource, Jovis Verlag GmbH, Berlin.

CLÉMENT, G. (2004). Manifesto del terzo paesaggio, Quodlibet, Macerata.

COSTA, J.P. (2013). Urbanismo e adaptação ás alterações climáticas as frentes de água, Lisvros Horizonte, Lisboa.

CONZEN, M.R.G. (2012). L'analisi della forma urbana Alnwick, Northumberland, Franco Angeli.

CRYER, P. (1996). The research student's guide to success, Open University Press, Buckingham.

CULLEN, H. (2010). The weather of the future. Heat waves, extreme storms, and other scenes from a climatechanged planet, Harper Collins ed., New York.

DIAS COELHO, C. (coord.) et al. (2013). Cadernos de Morfologia urbana da Cidade Portuguesa, n. 1 - Os Elementos Urbanos, Argumentum Lisboa.

DIXON HUNT, J. (2012). Sette lezioni sul paesaggio, Libria Milano.

FERREIRA, O. et al. (2008). Implications of sea-level rise for continental Portugal, in Jourban of Coastal Research, N. 242:317-324.2008, Coastal Education and Research Foundation.

IPCC (2007) Climate Change 2007: impacts, adaptation and vulnerability. CUP, Cambridge University press.

IPCC (2013) Climate Change 2013: The Physical Science Basis. Contribution of Working Group I to the Fifth Assessment Report of the Intergovern $\neg$ mental Panel on Climate Change T.F. Stocker, D. Qin, G.-K. Plattner, M. Tignor, S.K. Allen, J. Boschung, A. Nauels, Y. Xia, V. Bex and P.M. Midgley (eds.), Cambridge University Press: Cambridge, United Kingdom and New York, NY, USA, 2013. p. 1535.

IPCC (2014) Climate Change 2014: impacts, adaptation and vulnerability. Part A: global and sectoral aspects, CUP, Cambridge University press.

JACOBS, A.B. (1993). Great Streets, The MIT Press, Cambridge.

GREGOTTI, V. (1989). La strada: tracciato e manufatto. En Casabella 553- 554 Sulla strada / About Roads. (25). Milano: Mondadori.

MATOS SILVA, M. y COSTA, J.P. (2017). Urban Floods and Climate Change Adaptation: The Potential of Public Space Design when Accommodating Natural Processes. 
MURATORI, S. (1960). Studi per un operante storia urbana di Venezia, Roma, Libreria dello Stato.

NORDENSON, G. (2010). On the water. Palisade Bay. HATJE CANTZ, Princeton University School of Architecture.

OCHOA, A.R. (2010). Cidade e frente de água, papel articulador do espaço público, Dissertação para obtenção de grau de Doutor, apresentada na faculdade de Belles Arts, Barcelona.

PANERAI, P. et al. (1999). Analyse urbaine, Éditions Parenthèses, Marselha.

PROENÇA, S.B. (2014). A diversidade da rua na cidade de Lisboa, Dissertação para obtenção de grau de Doutor em Planeamento Urbanístico, apresentada na facultade de Arquitectura da Universidade técnica de Lisboa, Lisboa.

PURINI, F. (2000). Comporre l'architettura, Laterza Editori, Roma.

RAMOS PEREIRA, A. (2008). Sea level changes and neotectonics: some examples in Portugal (Arrábida and Southwest) in "Estudos do Quaternário, 5, APEQ, Porto, 2008, pp. 31-37.

ROSSI, A. (1966). L'architettura della città, Marsilio Editori, Venezia.

RIONDINO, A. (2012). Ludovico Quaroni e la didattica dell'architettura nella Facoltà di Roma tra gli anni '60 e '70: Il progetto della Città e l'ampliamento dei confini disciplinari, Cangemi Editore, Roma.

SECCHI, B. (1989). Lo spessore della strada. En Casabella 553-554 Sulla strada / About Roads, (38-41). Milano: Mondadori.

SECCHI, B., VIGANÒ P. (2011). La ville poreuse. Un projet pour le grand Paris et la métropole de l'après-kyoto, Metispresses.

TRAPERO, J.J. (1998). Los paseos marítimos españoles. Su diseño como espacio público, Akal Ediciones. VIGANÒ, P. (1999). La città elementare, SKIRA, Milano. 